\title{
JAK UMIERA PISARZ? ŚMIERCI UROJONE (MORTS IMAGINAIRES) MICHELA SCHNEIDERA JAKO NEKROFIKCJE
}

Pogrzeby pisarzy, nawet tak odmienne, jak przybierający formę patriotycznej manifestacji pogrzeb sprowadzonych z Paryża szczątków Mickiewicza w 1890 roku czy przełamujący konwencje ostatniego pożegnania pogrzeb Wisławy Szymborskiej w 2012 roku, wpisują zmarłych twórców w pewien oficjalny żałobny dyskurs, wobec którego jego jednostkowe doświadczenie umierania schodzi na drugi plan. Czy w śmierci pojedynczego pisarza jest rzeczywiście coś wyjątkowego? Czy umiera on w inny niż przeciętny człowiek sposób? W jaki sposób o niej opowiadać? Jak śmierć pisarza łączy się z jego pisaniem? Inspiracją do podjęcia tych rozważań jest wydany w 2003 roku zbiór biograficznych esejów zatytułowany Morts imaginaires (Śmierci urojone) Michela Schneidera ${ }^{1}$, w której francuski autor ukazuje ostatnie godziny życia bardziej lub mniej znanych pisarzy, koncentrując się na wypowiadanych przez nich w chwili śmierci słowach, wymyślając okoliczności, $\mathrm{w}$ jakich zostały one wypowiedziane oraz dopatrując się $\mathrm{w}$ ich życiu i dziełach powiązań ze śmiercią. Obok przywoływanych przez Schneidera ultima verba i ich narracyjnego statusu, interesować mnie będzie relacja prozy tego autora do tradycyjnego dyskursu (auto)biograficznego oraz jego współczesnych odmian, a także statusu owych fikcyjnych śmierci we współczesnym pisarstwie oraz we współczesnej kulturze: jaką rolę pełnią one w literaturze, w której autor-pisarz powraca dziś po zadeklarowanej przez Barthes'a jego

${ }^{1}$ M. Schneider, Morts imaginaires, Gallimard Folio, Paris 2004. Wszystkie cytaty podaję za tym wydaniem. Jeśli nie zaznaczono inaczej, tłumaczenie pochodzi od autorki artykułu. 
„śmierci”? Jaką rolę pełnią one we współczesnym świecie, w którym śmierć jest pomijana milczeniem?

Twórczość pisarska urodzonego w 1944 roku Michela Schneidera, absolwenta prestiżowej Ecole nationale d'administration i laureata kilku nagród literackich, stanowi niejako dopełnienie jego działalności jako wysokiego urzędnika państwowego, a przede wszystkim psychoanalityka. Obejmuje ona głównie, obok dwóch powieści, sytuujące się na pograniczu fikcji i dokumentu eseje biograficzne poświęcone m.in. Glennowi Gouldowi², Robertowi Schumanowi ${ }^{3}$, Teodorowi Géricaultowi ${ }^{4}$, czy relacji Marcela Prousta z matką . Niewątpliwy sukces osiągnął dzięki Marilyn: ostatnie seanse $e^{6}$, stanowiącej zapis odtworzonych seansów psychoanalitycznych hollywoodzkiej gwiazdy, jedynej książce tego autora przełożonej na język polski, za którą otrzymał przyznawaną dziennikarzom Prix Interallié oraz, stanowiące przedmiot rozważań w tym artykule, Morts imaginaires, za które otrzymuje Prix Médicis przyznawaną utalentowanym, choć niezbyt jeszcze uhonorowanym autorom. Spore zainteresowanie wzbudzają jego prace poświęcone stanowi współczesnej kultury politycznej, którą, podobnie jak życiorysy pisarzy i artystów, odczytuje według psychoanalitycznego klucza i w której dostrzega przejawy infantylizacji i powrotu do pewnej formy matriarchatu ${ }^{7}$, a także dzieła poświęcone związkom literatury i psychoanalizy ${ }^{8}$.

\section{Życie jako doświadczenie: autofikcje i biofikcje}

Trudno twórczości Michela Schneidera, tak wyraźnie nawiązującej do tradycji pisarstwa biograficznego i wchodzącej w dialog z psychoanalizą, nie odczytywać przez pryzmat konsekwencji, jakie przyniosła krytyka podmiotu literackiego dokonana $\mathrm{w}$ duchu strukturalistycznego paradygmatu filozoficzno-kulturowego we Francji w drugiej połowie XX wieku, która swój wyraz na gruncie teorii literatury znalazła w słynnej tezie Barthes'a o „śmierci autora" (1968), dokonującej zerwania między biografią autora a jego dziełem. Jak dziś wiadomo, tekstualna krytyka nie zlikwidowała podmiotu, lecz raczej przeformułowała pewną jego wizję. Od początku lat 80. podmiot "powraca” zarówno w refleksji teoretycznej (szczególnie Julii Kristevej, Michela Foucaulta

2 Tenże, Glenn Gould, piano solo: aria et trente variations, Gallimard, Paris 1988.

3 Tenże, La tombée du jour: Schuman, Seuil, Paris 1989.

${ }^{4}$ Tenże, Un rêve de pierre: le Radeau de la méduse: Géricault, Gallimard, Paris 1991.

5 Tenże, Maman, Gallimard, Paris 1999.

6 Tenże, Marilyn: ostatnie seanse, Znak, Kraków 2008.

7 Tenże, Big Mother: psychopatologie de la vie politique, Editions Odile Jacob, Paris 2002.

${ }^{8}$ M.in.: Tenże, Voleurs de mots: essai sur le plagiat, la psychanalyse et la pensée, Gallimard, Paris 1985. 
czy Paula Ricoeura), jak i praktyce literackiej (ku takiej zbliża się sam Barthes w swych późniejszych dziełach, to jest w Roland Barthes o sobie samym czy we Fragmentach dyskursu miłosnego). W przypadku tej ostatniej, za przejaw owego powrotu uznać można intensywnie rozwijające się od tego okresu we Francji pisarstwo pierwszoosobowe i osobiste, które nawiązuje do tradycyjnej autobiografii i zarazem ją przekracza, a także towarzyszące mu konceptualizacje literaturoznawcze próbujące opisać sytuację podmiotu literackiego w nowym kontekście. Popularnym staje się termin „,autofikcja”, zaproponowany w $1977 \mathrm{roku}$, a następnie opracowany przez francuskiego pisarza i krytyka literackiego oraz autora prac teoretycznych poświęconych autobiografii, Serge'a Dubrovsky'ego ${ }^{9}$. Termin ten został wkrótce przejęty i zdefiniowany w odmienny sposób przez innego francuskiego twórcę i krytyka, Vincenta Colonnę. U pierwszego z nich autofikcja stanowi pewien wariant autobiograficznego paktu Philippa Lejeune'a, u drugiego, rozumiejącego ów termin dość szeroko, rodzaj literackiej mitomanii, zmyślania na własny temat ${ }^{10}$. Pozostająca pod silnym wpływem psychoanalizy Lacana (część sztandarowego dzieła Serge'a Dubrovsky'ego pt. Syn (Fils) stanowi zapis seansu psychoanalitycznego ${ }^{11}$ ) autofikcja, przyczynia się do załamania tradycyjnego podziału na rzeczywistość i fikcję, uwalniając narracje od kryterium referencyjności. Autofikcja wydaje się tym samym skoncentrowana raczej na autentyczności doznań niż zdarzeń. O jej skuteczności (czyli właściwie umiejętności wprawiania czytelnika w błąd), pomimo fikcjonalnego charakteru, może świadczyć choćby zamieszanie, jakie powstało wokół książki Jerzego Kosińskiego Malowany ptak, którą odczytano jako zapis prawdziwej historii żydowskiego chłopca z czasów wojny, wbrew wyjaśnieniom autora, że historia jest zmyślona, ale oparta na jego własnych doświadczeniach ${ }^{12}$.

Jednocześnie, co uznać można za kolejny przejaw omawianego tu procesu, również począwszy od lat 80. obserwuje się wzmożone zainteresowanie indywidualnością, jednostką (individu) oraz rehabilitację spychanej dotąd na margines biografii ${ }^{13}$, zarówno jako gatunku (zwłaszcza pogardliwie traktowanej do pierwszej połowy XX wieku we Francji biografii literackiej), jak i heurystycznego narzędzia badania dzieła literackiego ${ }^{14}$. Stanowiła ona niejako

${ }^{9}$ J. Lis, Obrzeża autobiografii. O wspótczesnym pisarstwie autofikcyjnym we Francji, Wydawnictwo Naukowe UAM, Poznań 2006, s. 15.

10 Tamże, s. 25 oraz rozdział II.

11 Tamże, s. 20. Dyskusja nad związkami autofikcji z psychoanalizą, zob. s. 77-81.

12 Przypadek Kosińskiego przywołuje Jerzy Lis. Tamże, s. 66.

13 Tę rehabilitację prezentuje $\mathrm{w}$ obszernym studium poświęconym współczesnemu pisarstwu biograficznemu we Francji Martine Boyer-Weinmann (La Relation biographique: Enjeux contemporains, Editions Champ Vallon, collection „Détours”, Seyssel 2005).

14 Claude Arnaud mówi w ten sposób o „powrocie biografii” we współczesnej literaturze i krytyce literackiej. Zob. C. Arnaud, Le retour de la biographie: d'un tabou à l'autre, „Débat” nr 54, Mars-Avril 1989, s. 40-47. 
odpowiedź na panującą od słynnego eseju Marcela Prousta Contre Sainte-Beuve, a kontynuowaną przez strukturalistyczną teorię literatury biograficzną fobię, wynikającą z reakcji na panującą uprzednio metodę interpretacji dzieła literackiego w powiązaniu z biografią jego autora ${ }^{15}$. W tym nurcie - zainteresowani jednostką - sytuują się chętnie w ostatnich latach uprawiane przez francuskich autorów (zwłaszcza Patricka Modiano, Pascala Quignarda, Gérarda Macégo, Pierre'a Bergounioux, Pierre'a Michona) fikcje biograficzne, czyli właściwie fikcje literackie przybierające postać biografii i mówiące o życiu postaci wyobrażonej lub wyobrażonym życiu postaci rzeczywistej ${ }^{16}$, najczęściej pisarza lub artysty. Za inicjatora tego rodzaju opowieści, nazywanych niekiedy „biofikcjami" ${ }^{17}$ i nawiązującymi do tradycyjnego gatunku żywotów, uznaje się żyjącego w drugiej połowie XIX wieku symbolistę Marcela Schwoba i jego opublikowany w 1896 roku zbiór opowiadań zatytułowany Żywoty urojone (Vie imaginaires $)^{18}$. Teksty te, w których rzeczywistość i fikcja mieszają się w sposób nierozróżnialny, nie tylko podają w wątpliwość modernistyczne przekonanie o niereferencyjnym charakterze fikcji literackiej, ale zarazem, jak to podkreśla Alexandre Gefen, zrywają w ogóle z tradycyjnym rozumieniem literackiego przedstawienia na zasadzie mimesis, naśladowania i egzemplifikacji ${ }^{19}$. Skupiając się na prywatnym życiu opisywanych postaci, na jego niepowtarzalności, odwołują się raczej do prawdy uczuć niż prawdy zdarzeń, uruchamiając performatywną funkcję opowieści ${ }^{20}$.

Jak widzimy, zarówno pisarstwo autofikcyjne, jak i fikcje biograficzne, koncentrujące się na indywidualnym przeżyciu, a jednocześnie odwracające się od pojmowania fikcji literackiej w kategoriach reprezentacji, wpisują się w antropologiczny zwrot, jaki dostrzega współczesna „kulturowa teoria literatury" w humanistyce ostatnich lat, rehabilitujący kategorię ludzkiego doświadczenia, traktujący literaturę jako szczególne miejsce jego wyrażania

${ }^{15}$ M. Boyer-Weinmann, La Relation biographique..., dz. cyt., s. 16.

16 A. Gefen, Le Genre des noms: la biofiction dans la littérature française contemporaine, [w:] B. Blanckeman, A. André-Maura, M. Dambre (dir.), Le roman français au tournant du XXIe siècle, Presses Sorbonne, Nouvelle, Paris 2004, s. 305. Wydaje się, że taki rodzaj pisarstwa biograficznego, sytuującego się na granicy fikcji i rzeczywistości, prezentuje Renata Lis z niedawno opublikowaną książką pt. Ręka Flauberta (Sic!, Warszawa, 2011).

17 Termin taki zaproponował Alain Buisine, zob. Biofictions, „Revue des Sciences Humaines” („Le Biographique”) 1991, nr 224, s. 7-13.

18 Taki rodowód biofikcji, zarówno jeśli chodzi o ich inicjatora, jak i nawiązania gatunkowe, podaje Alexandre Gefen (Le Genre des noms..., dz. cyt., s. 307), choć z pewnością można by tu wymienić również Jorge L. Borgesa. W Polsce Żywoty urojone Marcela Schwoba ukazały się w przekładzie Leona Schillera (Towarzystwo Wydawnicze Ignis, Białystok 1924). Nie sposób nie wspomnieć tu także książki włoskojęzycznej szwajcarskiej pisarki Fleur Jaeggy, Żywoty domniemane (przeł. S. Kasprzysiak, Noir sur Blanc, Warszawa, 2011), która zawiera m.in. biograficzną fikcję o Marcelu Schwobie.

19 Tamże, s. 315 i 319.

20 Tamże, s. 319. 
i koncentrujący się na tym, co „idiosynkratyczne, jednostkowe, osobliwe”21. Ten zwrot, będący wyrazem kryzysu twardej refleksji teoretycznej, oddzielonej od swego przedmiotu badań i tworzącej hermetyczny metajęzyk opisu utrwalony na racjonalnych metodologicznych podstawach, oznacza również uznanie poznawczych funkcji fikcji literackiej, która zawiera pewną wiedzę, choć jej nie komunikuje ${ }^{22}$.

\section{Michel Schneider i ultima verba: między biografią a nekrografią}

Już sam tytuł zbioru esejów Michela Schneidera, Śmierci urojone, bo tak chyba należałoby go przełożyć (zwłaszcza, że wspomniany wcześniej autor Żywotów urojonych, Marcel Schwob, jest jednym z bohaterów zbioru) wydaje się wpisywać to dzieło w przedstawiony wyżej kontekst, choć z pewnością dostrzegamy w nim pewną przewrotną analogię. Schneider, przywołując postaci trzydziestu sześciu pisarzy z różnych epok, przyjmuje perspektywę końca ich życia, tworząc coś w rodzaju historii literatury à rebours, bowiem pod tytułem każdego eseju umieszcza nazwisko oraz datę śmierci pisarza i to właśnie te daty tworzą chronologię całego zbioru, od Michela Montaigne'a poczynając, a na Trumanie Capote kończąc ${ }^{23}$. W ten sposób książka, zarówno jej poszczególne eseje, jak i cały zbiór, wydaje się w pierwszym momencie uchodzić za przykład tego, co Stanisław Rosiek nazywa, zajmując się szczególnie przypadkiem Adama Mickiewicza, „nekrografią”, czyli opowieścią, jaka narosła wokół postaci zmarłego poety, a szczególnie jego zwłok - pośmiertny kult, jakim otoczono twórcę ${ }^{24}$. Nekrografia jest w pewnym sensie „drugim życiem" poety, wynikającym z horacjańskiego przekonania o jego trwaniu we własnych dziełach i wywodzącym się stąd przeświadczeniu o jego wyjątkowości. Pozostaje w związku rozprzestrzeniającym się w całej XIX-wiecznej

${ }^{21}$ R. Nycz, Antropologia literatury, kulturowa teoria literatury, poetyka doświadczenia, „Teksty Drugie" 2007, nr 6, s. 44.

22 Tamże, s. 39.

${ }^{23}$ Scheider przywołuje w poszczególnych esejach następujących autorów: Michel de Montaigne, Blaise Pascal, Mme de Sévigné, Julie de Lespinasse, François Arouet (Voltaire), Madame du Deffand, Emmanuel Kant, Benjamin Constant, Johann Wolfgang von Goethe, Aleksander Puszkin, Henri Beyle (Stendal), François René de Chateaubriand, Honoré de Balzac, Heinrich Heine, Thomas De Quincey, Aleksander Dumas, Gustave Flaubert, Guy de Maupassant, Antoni Czechow, Marcel Schwob, Jean Lorrain, Lew Tołstoj, Rainer Maria Rilke, Catherine Pozzi, Sigmund Freud, Walter Benjamin, Marina Cwietajewa, Stefan Zweig, Hermann Broch, Robert Walser, Dorothy Parker, Alexandre Vialatte, Dino Buzzati, Vladimir Nabokov, Jean Rhys, Truman Capote.

${ }^{24}$ S. Rosiek, Zwłoki Mickiewicza. Próba nekrografii poety, słowo/obraz terytoria, Gdańsk 1997. 
Europie kulcie zmarłych ${ }^{25}$. Jak stwierdza Rosiek, w śmierć poety wpisany jest paradoks, bowiem usuwa ona człowieka z historii jako ciągu zdarzeń, umieszczając go jednocześnie w historii rozumianej jako dyskurs ${ }^{26}$. Należąca do tego dyskursu nekrografia pozwala niejako uporać się ze skandalem, jaki dla żyjących stanowi śmierć, zastępując opowieść o życiu, biografię, opowieścią o śmierci: „Śmierć jest skandalicznym wydarzeniem, które rozsadza ramy biograficznego dyskursu. Domaga się innych zasad budowania wypowiedzi na swój temat, zmiany hierarchii przez biografię przyjmowanych, reorientacji układu napięć (...)"27.

Tak więc choć biografia opowiada o życiu, a nekrografia o śmierci, należą one do tego samego porządku narracyjnego i oddalone są od bezpośredniego doświadczenia - odpowiednio - życia i śmierci. Jednocześnie są tu uruchamiane odmienne porządki czasowe, publiczny czas historyczny, do którego należałyby biografia i nekrografia oraz prywatny czas indywidualnego losu, związane z jednostkowym doświadczaniem śmierci, o których mówi Ricoeur w Czasie i opowieści ${ }^{28}$. Wydaje się, że w tym właśnie sensie nekrografia nie jest przeciwieństwem biografii, ale jej dopełnieniem, choć Rosiek rozumie to powiązanie w nieco inny sposób:

Sądzę, że zajmowanie się zmarłym - a mówiąc dobitniej: jego zwłokami, trupem, resztkami, prochem (...), powiększa naszą wiedzę o osobie, że - wobec tego - biografię powinna dopełniać nekrografia; dopiero obydwie łącznie obejmują całość czyjejś, także pośmiertnej, egzystencji ${ }^{29}$.

Niemniej jednak nekrografia, która narusza intymność zmarłego, czyniąc z niego samego i z jego ciała przedmiot żałoby i kultu oraz wpisując je w historyczny dyskurs, może być odczytana jako wyraz niezgody na śmierć i w tym sensie należałaby do nowoczesności. Bowiem nowoczesny dyskurs historiograficzny, jak stwierdza Michel de Certeau, na skutek odmiennego niż w kulturach tradycyjnych pojmowania śmierci na Zachodzie, gdzie nie akceptuje się jej jako integralnej części życia, właściwie doświadczenie śmierci wyklucza ${ }^{30}$. Stąd zachodni dyskurs nauk o człowieku de Certeau nazywa "pato(-)logicznym", w pierwotnym sensie słowa patos, dyskursem nieszczęścia i pełnego pasji działania ${ }^{31}$. Przekształcenie doświadczenia śmierci w dys-

${ }^{25}$ Tamże, s. 61.

${ }^{26}$ Tamże, s. 55 i 57.

27 Tamże, s. 108-109.

28 P. Ricoeur, Czas i opowieść, t. 3, Czas opowiadany, przeł. U. Zbrzeźniak, Wydawnictwo Uniwersytetu Jagiellońskiego, Kraków 2008, s. 163. Śmierć według Rioeura posiada tym samym niejasne znaczenie $\mathrm{w}$ pisaniu historii, odnosząc się zarazem do intymnego doświadczenia każdego człowieka, jak i do publicznego charakteru następstwa pokoleń. Zob. tamże, s. 165.

29 S. Rosiek, Zwłoki Mickiewicza..., dz. cyt., s. 110.

${ }^{30}$ M. de Certeau, Pismo historii, przeł. K. Jarosz, „Er(r)go” 2001, nr 3, s. 119-120.

${ }^{31}$ Tamże, s. 120. 
kurs historyczny byłoby więc cechą kultury zachodniej i konsekwencją obowiązującej w niej linearnej koncepcji czasu. W przypadku pisarza czy poety, niezgoda na śmierć równa się właściwie niezgodzie na jego zamilknięcie, które ta niechybnie powoduje. Stąd nekrografia Mickiewicza jest przede wszystkim próbą przywrócenia poecie nie tyle życia, co mowy ${ }^{32}$. Zmarły Mickiewicz rewanżuje się za ten gwałt na jego szczątkach powracając w postaci „budzącego strach i grozę wampira" 33 .

Powróćmy jednak do Śmierci urojonych. Ostatnim słowom pisarzy, które stanowią punkt wyjścia do rozważań Schneidera, przypisywane jest $\mathrm{w}$ tradycji literackiej szczególne znaczenie. Nie tylko z powodu specyficznego momentu ich wypowiadania, pomiędzy życiem a śmiercią, ale głównie z powodu wypowiadania ich właśnie przez pisarzy. Zapamiętywane, interpretowane, a nawet przeinaczane przez świadków i biografów, gdy ich język, będący w opinii powszechnej miarą literackości, nie jest wystarczająco "piękny" i „literacki” (s. 42), ostatnie słowa nie tylko przynależą do przedstawionego powyżej nekrograficznego dyskursu, budującego pośmiertny kult autora, ale także stanowią zakończenie oficjalnej biografii. Tym samym wydają się być przejawem rozdzielnego pojmowania dzieła twórcy i jego życia, odłączania dzieła od bezpośredniego doświadczenia, a także estetyzację śmierci, pomijającą rzeczywiste jej przeżywanie przez pisarza, czy lęk przed nią. W powszechnym bowiem przekonaniu, jak stwierdza Schneider, właśnie w tych kończących życie słowach, a więc ani nie $\mathrm{w}$ dziełach pisarza, ani nie w brutalności śmierci, „lepiej daje się usłyszeć prawdę i dostrzec piękno” (s. 17). Ultima verba, podobnie jak biografia i nekrografia, których część stanowią, są mistyfikacją, bowiem „nawet jeśli dyktował je strach, niemal zawsze zostaną odziane przez żyjących w odwagę i spokój ducha" (s. 41), a wypowiadający je autorzy traktowani są jak przegrywający wprawdzie, ale z godnością, bohaterowie, którym przysługuje wyłącznie „heroiczna, bądź łagodna śmierć" (s. 41). Ich wiarygodność pod wieloma względami może tym samym budzić wątpliwość:

Czy jednak śmierć jest tym, co zaczyna się po tym, jak zamilkną słowa? Czy schowane pod maską pragnienia łagodnej śmierci ultima verba jakiegoś autora są rzeczywiście ostatnimi? Czy zawsze chodzi o słowa? I czy zawsze o słowa pisarza? I czy o ostatnie w sensie czasowym? Kto wie, że były to właśnie słowa? (s. 27).

Tak więc, wychodząc od legendarnych ostatnich słów, a także przekonania o zawartych w nich prawdzie i pięknie życia oraz jego końca, Schneider dokonuje dekonstrukcji zarówno nekrograficznego, jak i biograficznego dyskursu, grając przez wszystkim z linearnym i publicznym porządkiem czaso-

\footnotetext{
32 S. Rosiek, Zwłoki Mickiewicza..., dz. cyt., s. 266.

${ }^{33}$ Tamże, s. 122.
} 
wym, do których przynależą. W ten sposób, na przykład, podaje kilka wersji opowieści o śmierci Balzaca, oddając głos Wiktorowi Hugo, malarzowi Jeana Gigoux, kochankowi pani Hańskiej ${ }^{34}$, wreszcie samemu Balzacowi w pseudoautobiograficznej opowieści o jego własnej śmierci, albo przywołuje napisaną przez Thomasa De Quincey'a biografię Immanuela Kanta, skomponowaną z istniejących już wcześniej opowieści o śmierci filozofa. Dyskredytuje tym samym wiarygodność oficjalnych opowieści o śmierci pisarza. Podobnie odnosi się także do dyskursu biograficznego, ze względu na przyjętą $\mathrm{w}$ nim $\mathrm{z}$ góry perspektywę życia, którą podaje w wątpliwość słowami Georgesa Bernanosa: „Dlaczego mówi się »kroczyć przez życie«"? pisał Georges Bernanos. „Kroczymy zawsze ku śmierci, to naszą śmierć bez ustanku zgłębiamy, a także z trudem pojawiające się dzieło" (s. 25).

Właściwsze, bo bardziej realne wydaje się spoglądanie na życie z perspektywy śmierci, nie pojmowanej jednak jako koniec życia, lecz jako doświadczenie leżące u podstaw ludzkiej egzystencji, stanowiąca przedmiot rozważań, lęków, zmagań. Śmierć bowiem niekoniecznie następuje po ostatnich słowach, ale często jest antycypowana, wymyślana, aranżowana przez pisarzy jeszcze za życia w ich dziełach, a więc pojawia się avant la lettre, w dosłownym sensie tego wyrażenia. $\mathrm{W}$ ten sposób „dla pisarzy nie istnieją ostatnie słowa. Albo też wszystkie jego słowa są ostatnimi" (s. 25). Między pisaniem a śmiercią istnieje tym samym szczególna więź wynikająca z całkowitej identyfikacji z własnym pismem: Catherine Pozzi zapisuje w swoim dzienniku, że „chodzi tylko o pisanie i o umieranie" (s. 266), Hermann Broch uznaje, że literatura jest poznaniem śmierci i „nienawidził we współczesnym świecie ucieczki od wszelkiej myśli od [niej - przyp. K.T.J.]” (s. 322), a w eseju o Zweigu sam już Schneider stwierdza, że „nasza śmierć nie przychodzi w sposób, w jaki żeśmy sobie to wyobrazili albo jakiego obawiali, ale niekiedy przydarza się tak, jak żeśmy to napisali" (s. 315). Więź pomiędzy autorem a jego dziełem nie jest więc symboliczna, lecz raczej fizyczna, realna, co zaprzecza próbom ich rozdzielania przez nowoczesny dyskurs i czyni z poszczególnych książek (choć nie z literatury w ogóle) materialne przedłużenie egzystencji autora, zastępujące wręcz jego nieobecne ciało. W specyficzny sposób potwierdza to Chateaubriand, który, sprzedawszy przed własną śmiercią za dożywotnią rentę swe opus posthumum, żyje z niego jeszcze przez dwanaście lat. Ów schizofreniczny stan zasadniczo odróżnia, zdaniem Schneidera, istnienie pisarza od istnienia zwykłego człowieka: „Tak więc chwila, gdy oceniamy nieuchron-

${ }^{34}$ Michel Schneider wykorzystuje tu fragmenty opublikowanego w 1907 roku przez francuskiego pisarza i krytyka Gustava Mirbeau (1848-1917) skandalizującego tekstu pt. La mort de Balzac (Śmierć Balzaca), w którym Mirbeau sugeruje związek Hańskiej z Gigoux i czyni tego ostatniego narratorem opowieści o ostatnich chwilach powieściopisarza, nie szczędząc pikantnych szczegółów. 
nie ciało, w którym znikniemy, i od którego, jak sądzimy, myśl się nareszcie odłączy, przywodzi pisarza do granic owego ciała bez ciała, które otrzymujemy w książkach" (s. 401).

Zawłaszczeniu śmierci, a ściślej mówiąc, ciała zmarłego pisarza przez dyskurs nekrograficzny sprzeciwiają się sami twórcy, którym nie zawsze zależy na umieszczaniu ich w panteonie wielkich pisarzy oraz na uznaniu potomnych: umierający Balzac w eseju Schneidera obawia się, że „zabiorą mu jego śmierć, tak jak ona zabrała mu życie” i że „przebiorą go za wielkiego pisarza" (s. 164). Autor Śmierci urojonych zdaje sobie sprawę z mechanizmu stłumienia, jaki uruchamiany jest przez dyskurs nekrograficzny: „żałobne rytuały służą żywym, aby upewnić się, że zmarli nigdy już nie powrócą, ale na zawsze pozostaną z drugiej strony" (s. 392). Pisarze zabezpieczają się przed owym stłumieniem próbując mieć wpływ zza grobu na los ich własnych ciał, lecz najczęściej opór ten jest bezsilny. Niezależnie od Schneidera francuski pisarz i krytyk Michel Ragon przywołuje na przykład uroczystą ceremonię pogrzebową Wiktora Hugo, podczas której umieszczono trumnę, na własne życzenie wielkiego poety wyrażone $\mathrm{w}$ jego testamencie, na prostym karawanie dla biednych ${ }^{35}$. Nie przeszkodziło to jednak, jak wiadomo, złożeniu jego ciała w 1885 roku w paryskim Panteonie i wykorzystaniu tej ceremonii do tworzenia symboliki młodej wówczas Trzeciej Republiki Francuskiej.

\section{Nekrofikcje: śmierć jako plagiat}

Kwestionując wiarygodność dyskursu biograficznego i nekrograficznego poprzez demaskowanie ich fikcyjnego charakteru, wynikającego $\mathrm{z}$ estetyzacji momentu śmierci oraz $\mathrm{z}$ ich funkcjonowania $\mathrm{w}$ czasie publicznym i linearnym, Schneider rozprawia się w swoim eseju także $\mathrm{z}$ istniejącym od epoki nowożytności kultem autora, zbudowanym na przekonaniu o oryginalności pisarskiego stylu jako wyrazu jego indywidualności ${ }^{36}$. W sporze Prousta z Sainte-Beuvem, w którym styl pisarza przeciwstawiony zostaje jego życiu, Schneider wybiera trzecią drogę, biorąc za punkt wyjścia śmierć: „Dla pisarza umrzeć, to porzucić fikcję książki, fikcję, jaką stanowi autor. [Stać się - przyp. K.T.J.] rzeczą pośród innych rzeczy" (s. 370).

${ }^{35}$ M. Ragon, Pogrzeb-widowisko, przeł. A. Peccorari, [w:] S. Rosiek (red.), Wymiary śmierci, słowo/obraz terytoria, Gdańsk 2010, s. 340.

${ }^{36}$ M. Proust, W zwiazku ze "stylem" Flauberta, przeł. M. Bieńczyk, [w:] Pamięć i styl, wybór, opracowanie, wstęp M.P. Markowski, Znak, Warszawa 2010, s. 158: „Każdy pisarz musi sobie sprawić własny język, tak jak skrzypek musi znaleźć swój »ton« (...). Nie chcę przez to powiedzieć, że podobają mi się oryginalni, choć źle piszący (...). Dopiero wtedy jednak zaczynają oni pisać, gdy są oryginalni, gdy wynajdują własny język" (tamże, s. 222). 
W tym zdaniu, pozornie tylko nawiązującym do sformułowania Barthes'a koronującego strukturalistyczną epokę w teorii literatury, kryje się projekt pisania, który Schneider odnajduje w pierwszym rzędzie u autorów będących bohaterami jego książki. Pisząc bowiem nie dla "przyszłych czytelników" (s. 30), lecz "dla swych zmarłych poprzedników” (s. 30), ci sami autorzy są przede wszystkim czytelnikami. Fascynacja dziełami poprzedników posuwa się jednak niekiedy tak daleko, że identyfikują się oni ze zmarłymi, widząc w ich życiu, a jeszcze bardziej w ich śmierci, scenariusz dla własnej. Skrajny przypadek takiej fascynacji stanowi przywoływany przez Schneidera Stefan Zweig, który swą samobójczą śmierć zapożycza od Heinricha von Kleista ${ }^{37}$. Wraz ze swą wzorowaną na samobójstwie Kleista śmiercią, Zweig ustanawia nowy gatunek literacki, ,"śmierci równoległe” (s. 303), rodzaj dosłownego pastiszu dzieła Plutarcha. Także Marcel Schwob, będący niejako patronem książki Schneidera, umiera w podobny sposób, jak jego literacki analogon, Robert Louis Stevenson. Ów "demon analogii” (s. 301), a także wspomniane już ścisłe powiązanie pisania ze śmiercią, sprawiają, że śmierć pojedynczego pisarza jest zawsze lustrzanym odbiciem innej, rzeczywistej bądź wyobrażonej, śmierci.

Jak więc pisać o śmierci pisarza, aby z jednej strony uniknąć pułapek oficjalnego dyskursu, a z drugiej umożliwić powrót wypartego przez ów dyskurs zmarłego? Taką możliwość Schneider wydaje się dostrzegać w sposobie pisania, który funkcjonuje na obrzeżach oficjalnej biografii i nekrografii, a jednocześnie pozbawiony jest hermeneutycznych ambicji scalania życia pisarza w obdarzoną sensem całość oraz pretensji do oryginalności. Schneider w oficjalnych biografiach autorów doszukuje się więc mało istotnych z punktu widzenia historii szczegółów, niekiedy wręcz wstydliwych czy godnych pożałowania, a w ostatnich słowach interesuje go przede wszystkim proces pogłębiającej się niesprawności języka, utrata zdolności budowania sensownej wypowiedzi. Zasadnicza funkcja takiego sposobu pisania, który określiłabym jako "nekrofikcje” i który prezentują omawiane tu przeze mnie Śmierci urojone, wydaje zawierać się w pytaniu: "Czyż pisanie to nie sposób przywoływania zmarłych?” (s. 146). Polegałby on nie tyle na tworzeniu wiarygodnej (tzn. referencyjnej) opowieści o zmarłym bądź jego nieżywym ciele, co na ujawnianiu owej gry lustrzanych odbić dokonującej się pomiędzy śmiercią a pismem, w jaką uwikłany jest każdy pisarz. Podobnie jak nekrografia miała być $\mathrm{w}$ pewnym sensie kontynuacją biografii, tak nekrofikcje byłyby przedłużeniem wspomnianych na początku tego artykułu biofikcji, uzupełniając opowieść o doświadczeniu życia opowieścią o doświadczeniu śmierci. Analogia ta potwierdzona jest przez samego Michela Schneidera, który traktuje

37 Ten niemiecki poeta i dramaturg znany jest z drobiazgowo i z rozmysłem przygotowanego samobójstwa, które popełnił wraz ze swoją przyjaciółką Henriettą Vogel. 
swe dzieło jak negatyw Żywotów urojonych Marcela Schwoba, stanowiących dla niego ,jasne lustro, w którym szuk[a] [sw]ych ciemnych Śmierci urojonych [przyp. - K.T.J.]" (s. 229). Nie ogranicza się ona oczywiście tylko do intertekstualnego nawiązania w tytule, lecz polega na zapożyczeniu od Schwoba sposobu konstruowania nekrograficznych fikcji:

W 1899 roku Schwob tłumaczy i publikuje w czasopiśmie La Vogue coś w rodzaju śmierci urojonej (...) Immanuela Kanta, wymyślonej przez Thomasa De Quincey'a na podstawie różnych opowieści. Zdefiniował tam podejście, które stało się moją jedyną metodą: pokochać inteligencję pisarza, najjaśniejsze światło, w chwili, gdy zaczyna przygasać i przyłożyć do jego wymyślonego życie fałszywą pieczęcią rzeczywistości (s. 230).

Znajdując usprawiedliwienie u samego Schwoba, który stwierdza, że „pisząc zawsze naśladujemy, nawet wbrew naszej woli” (s. 237), Schneider dokonuje właściwie jawnego plagiatu, który zabezpiecza go przed pokusą tworzenia własnej fikcji autora, o której była mowa wyżej. W innym swoim dziele, zatytułowanym Voleurs de mots (Złodzieje słów) ${ }^{38}$, wyraźnie zresztą przywraca do łask tę funkcjonującą od dawna w literaturze, a uznawaną od epoki nowożytności kultywującej oryginalny styl za niegodną praktykę, rozumiejąc ją w duchu psychoanalizy jako lustro słów i myśli, które wystawia ku nam ktoś inny. Za nekrofikcjami, jakimi są Śmierci urojone, kryje się $\mathrm{w}$ ten sposób również pewien projekt autobiograficzny, choć Schneider jest świadomy, że pisanie „autotanatografii” (s. 20), pisanie o sobie jako o zmarłym, z logicznych powodów nie jest możliwe. Wiąże go zatem raczej ze swą aktywnością czytelnika i plagiatora, która właściwie polega na wyzbywaniu się siebie, aby stać się lustrem dla innych: „jestem moimi zmarłymi pisarzami” (s. 392), "powinienem był zatytułować tę książkę Zwierciadło zmarłych" (s. 394) oraz odkrywaniu śladów pozostawionych przez innych czytelników w książkach, którzy w ten sposób organizują jego własną lekturę, czyniąc z niego właściwie czytelnika-plagiatora. Owo czytanie-stawanie-się-innymi-pisarzami, przybierające wręcz fizyczną postać (Schneider traktuje książki jako "fragmenty siebie” czy swe „fantomiczne ciało" - s. 401), to ostatecznie zażegnywanie śmierci, lecz w słabej, nieheroicznej postaci.

Śmierci urojone Michela Schneidera, które nazwałam w moim artykule "nekrofikcjami”, sytuujące się na granicy fikcji i rzeczywistości oraz skupiające się indywidualnym doświadczeniu śmieci pisarza, przywracają zarówno literaturze, jak i kulturze dwie wyparte z oficjalnego dyskursu kategorie: zmarłego autora, który odzyskuje przerwaną więź ze swym dziełem, choć na sposób cielesny raczej niż językowy, a sam powraca jako duch, oraz samą śmierć, powracającą jednak w sposób słaby i jednostkowy, jako odbicie cu-

${ }^{38}$ M. Schneider, Voleurs de mots: essai sur le plagiat, la psychanalyse et la pensée, Gallimard, Coll. Tel, Paris 1984. 
dzej śmierci. Książka ta może być również odczytana jako projekt pewnej krytyki literackiej, nawiązującej do dawnej metody biograficznej, lecz zarazem ją przekraczający. Nie tylko ze względu na zawartą $w$ niej sugestię czytania dzieł w perspektywie śmierci ich autorów, lecz również ze względu na proponowany język, który, choć dzieło wyraźnie nawiązuje do wielkich tematów psychoanalizy (śmierć, fascynacja, lustrzane odbicia, stłumienie...), nie korzysta jednak z jej terminologii i pozostaje językiem literatury. Zatrzymujące się na progu interpretacji nekrofikcje byłyby może raczej tym, co Pierre Bayard określa jako „literatura stosowana” (również do psychoanalizy) ${ }^{39}$, a więc odwrotnie, niż koncepcja „psychoanalizy stosowanej” Freuda, pomysłu bazującego na przekonaniu o istnieniu w literaturze pewnej wiedzy, niepotrzebującej jednak teoretycznego opracowania; pomysłu pozostającego tym samym w związku ze Schneiderowskim pojmowaniem pisania: „Pisarstwo nie jest sposobem mówienia prawdy, lecz powoływaniem do istnienia. To, co nie jest zapisane, znika" ${ }^{40}$.

\title{
How does a writer die? Michel Schneider's Morts imaginaires as necrofiction
}

\author{
Sum mary
}

The starting point of Michel Schneider's Morts imaginaires, which refers to Vies imaginaires of the Belgian symbolist writer Marcel Schwob, is ultima verba, i.e. the last words that could probably be said by dying writers in various times. However, by choosing to talk about them from the perspective of death, the French author does not want to participate in the "necrographical", official discourse of a writer's death or in the biographical (historical) discourse, which do not respect the personal and singular experience of death. In this way, literary fiction about the experience of dying, which is here called "necrofiction" and which is legitimized by a psychoanalytic approach to the imaginary, becomes an alternative to the official forms of discourse about death or life.

${ }^{39}$ Zob. P. Bayard, Peut-on appliquer la littérature à la psychanalyse?, Les Editions de Minuit, Paris 2004. Krytycznie wobec "psychoanalizy stosowanej” wypowiada się sam Schneider, zob. Le Psychanalyste appliqué, „Revue Française de Psychanalyse” 2010/2, t. 74, PUF, s. 339-350.

${ }^{40}$ M. Schneider, Le Psychanalyste appliqué, „Revue Française de Psychanalyse” 2010/2, t. 74, PUF, s. 349. 